\title{
Viral entry pathways: the example of common cold viruses
}

\author{
Dieter Blaas
}

Received: 1 January 2016 / Accepted: 12 April 2016 / Published online: 12 May 2016

(C) The Author(s) 2016. This article is available at SpringerLink with Open Access

Summary For infection, viruses deliver their genomes into the host cell. These nucleic acids are usually tightly packed within the viral capsid, which, in turn, is often further enveloped within a lipid membrane. Both protect them against the hostile environment. Proteins and/or lipids on the viral particle promote attachment to the cell surface and internalization. They are likewise often involved in release of the genome inside the cell for its use as a blueprint for production of new viruses. In the following, I shall cursorily discuss the early more general steps of viral infection that include receptor recognition, uptake into the cell, and uncoating of the viral genome. The later sections will concentrate on human rhinoviruses, the main cause of the common cold, with respect to the above processes. Much of what is known on the underlying mechanisms has been worked out by Renate Fuchs at the Medical University of Vienna.

Keywords Endocytosis · Rhinovirus · Genome release · Lysosome $\cdot$ Uncoating

\section{Wege des Viruseintritts: am Beispiel der Erkäl- tungsviren}

Zusammenfassung Bei der Infizierung schleusen Viren ihr Genom in die Wirtszelle ein. Deren Nukleinsäuren befinden sich gewöhnlich gut verpackt innerhalb des Viruskapsids, welches wiederum häufig zusätzlich von einer Lipidmembran umhüllt ist. Beides schützt sie vor einer feindlichen Umgebung. Proteine

\section{Blaas ( $\bowtie)$}

Max F. Perutz Laboratories, Department of Medical Biochemistry, Medical University of Vienna, Vienna Biocenter, Dr. Bohr Gasse 9/3, 1030 Vienna, Austria e-mail: dieter.blaas@meduniwien.ac.at und/oder Lipide auf dem Viruspartikel unterstützen die Anlagerung an die Zelloberfläche und die Internalisierung. Ebenso sind sie oftmals an der Freisetzung des Genoms in der Zelle beteiligt, welches als Vorlage für die Produktion neuer Viren dient. Im Folgenden werden die frühen, eher allgemeinen Schritte der Virusinfektion kursorisch dargestellt, dazu gehören Rezeptorerkennung, Aufnahme in die Zelle und Freisetzung des Virusgenoms. Im Hinblick auf die genannten Abläufe liegt der Schwerpunkt in den weiteren Abschnitten auf humanen Rhinoviren als Hauptursache für den Schnupfen. Viele der bisherigen Erkenntnisse in Bezug auf die zugrunde liegenden Mechanismen sind von Renate Fuchs, Medizinische Universität Wien, erarbeitet worden.

Schlüsselwörter Endozytose $\cdot$ Rhinovirus · Genomfreisetzung $\cdot$ Lysosom $\cdot$ Kapsidöffnung

\section{Introduction}

The first encounter between a virus and its host cell usually takes place via a protein, a proteoglycan, an oligosaccharide, or a glycolipid exposed on the cell surface that is recognized by cognate viral surface components. Only few viruses can subsequently penetrate directly from the plasma membrane into the cytosol of the host cell; the large majority rather exploits cellular entry pathways by travelling inside a membrane vesicle. Under physiologic conditions, these cell surface molecules serve as nutrient transporters or signal transduction receptors, or in cell-cell interactions and attachment, amongst other things. In the context of viral infection they have been termed "viral receptors" although the cell obviously does not make them for the purpose of becoming infected. 
Viruses not only abuse membrane receptors but also soluble molecules, as a bridge to a plasma membrane protein or to bind to virus-specific antibodies that are present in the serum as a consequence of a previous infection. The latter, in turn, can then bind Fc $\gamma$-receptors present at the surface of some specialized cells and thus link the virus to them. For instance, virus-specific immunoglobulin G (IgG) can enhance infection by various flaviviruses, including, e.g., Dengue virus, rather than protecting the host against infection [1]. Other examples are the binding of apolipoprotein- $E$ to both hepatitis $C$ virus and heparan sulfate proteoglycans, which also leads to a connection between the virus and a cell surface component [2], and growth arrest-specific 6 (Gas6) bridging TAM receptors (various receptor tyrosine kinases) with phosphatidylserine that is present in the viral lipid membrane of Dengue and Vaccinia virus [3]. So, viruses have evolved to make use of whatever is available for attaching to and entering the host cell. Clearly, the presence or absence of a cognate viral receptor is a major but not the only factor in species and tissue tropism of a given virus [4]. It is of note that targeting viruses with oncolytic potential to tumors for their infection and destruction has been achieved by copying and exploiting this strategy [5].

Following the mutual recognition, the viral particle is taken up into the cell, either constitutively or triggered through its interaction with the receptor. The many identical subunits of a virion (i.e., a viral particle) render it multivalent; this can lead to clustering of, e. g., receptor tyrosine kinases or of integrins. For example, Vaccinia virus triggers activation of phosphatidylinositol 3-kinase (PI3K)/Akt in an integrin $\beta 1$ dependent manner, suggesting that this particular signaling pathway is essential for virus endocytosis [6]. Entry into the cell then engenders lipid vesicle trafficking processes. Reminiscent of the natural ligand, most intruding viruses become trapped where shallow membrane pits form; upon further membrane bending, a deep invagination is produced and finally severed from the plasma membrane in the form of a closed vesicle. The vesicle pinches off the inner side of the plasma membrane and carries its viral cargo, together with some extracellular fluid, through the crowded cytoplasm towards its intracellular destination. The transport vesicles undergo maturation by fusing with other vesicles, severing, and content sorting, all taking place during their voyage inside the cell. The vesicular membrane composition and intravesicular milieu continuously change along this route. Molecular machines, such as dyneins and kinesins, are involved in transporting virus-containing vesicles—or free virus particles-along actin fibers or microtubules [7-9].

Material inside the vesicle lumen is topologically extracellular and thus requires that either the entire virus or at least its genome penetrate the delimiting membrane to attain the cytosol. This occurs as soon as membrane composition, $\mathrm{pH}$, ionic environment, etc. have become optimal for this process and a given virus; it can happen in early endosomes, late endosomes, recycling endosomes, macropinosomes, the endoplasmic reticulum, in various subcompartments of the Golgi, and even in lysosomes with their interior full of hostile hydrolytic enzymes.

Membrane penetration is usually preceded by or occurs in concert with conformational changes of viral surface proteins and/or the whole virion shell itself. In many cases, these structural changes require that an envelope protein, such as the hemagglutinin of influenza viruses, has been proteolytically cleaved during maturation [10]. A hydrophobic or amphiphilic fusion peptide then becomes exposed and inserts into the plasma membrane; in non-enveloped viruses, membrane destabilization or even disruption is brought about by the release of "membranolytic peptides", small amphipathic viral proteins [11]. Another means of membrane destabilization was shown for canine parvovirus, which has a phospholipase $\mathrm{A}(2)$-like domain in the $\mathrm{N}$-terminus of its capsid protein VP1, whose enzymatic activity makes the membrane permeable for dextran of $3 \mathrm{kD}$ but not of $10 \mathrm{kD}$ [12]. Recently, the perfidiousness of viral entry has been demonstrated for adenovirus; this virus induces small pores via its membrane lytic protein-VI, which triggers calcium-mediated lysosomal exocytosis repair pathways and lipid signaling that finally facilitates uptake of the pathogen [13]. In all these cases, once the nucleic acid(s) has arrived in the cytosol, depending on the type of virus and the nature of its genome, replication is either initiated right there, or after it has been shuttled to the nucleus.

The present article is aimed at providing a brief overview on these early events of viral infection. Its extent is far from covering all aspects of these complex and in part poorly understood processes. I apologize for citing only few, mostly recent and in part arbitrarily chosen publications referring to examples out of the about 17,500 papers found in a PubMed literature search for "virus AND entry" at the time of writing. For recent excellent and more in-depth reviews on viral entry and uncoating, see, for example, [14-23].

\section{Naked and enveloped viruses}

Viruses come essentially in two distinct flavors; either carrying a lipid membrane envelope decorated with viral proteins, or naked, i.e., without any lipid. The former have built-in machinery for penetration of their capsid into the cytosol via fusion of viral with cellular membranes. Most often, this process is triggered by the acid environment $(\mathrm{pH}$ between about 5 and 6) established inside the endocytic vesicles during their maturation into late endosomes [24-26]; there are only few viruses, including human immunodeficiency virus (HIV) and herpes simplex virus-1, which do not require an acidic environment and can 
Fig. 1 Fusion of enveloped viruses with a cellular membrane. a A viral envelope protein (often a trimer, as depicted) harbors a fusion peptide that is poorly solvent accessible. b On exposure to the acidic $\mathrm{pH}$ inside endosomes, structural changes occur that result in exposure of the fusion peptide and its insertion into the endosomal membrane. c Conformational rearrangements of multiple envelope proteins (just one trimer is shown) force the membranes into close apposition resulting in hemifusion without a fusion pore and only partial mixing of the lipids in one of the leaflets. d Complete fusion resulting in the nucleoprotein/nucleic acid (brown) accessing the cytosol. $V$ virus, $H$ host, $(V)$ designates the residual viral membrane patch that remains after the contents have been transferred into the cytosol. Note that it finally becomes completely integrated into the host membrane with mixing of the lipids (not shown)
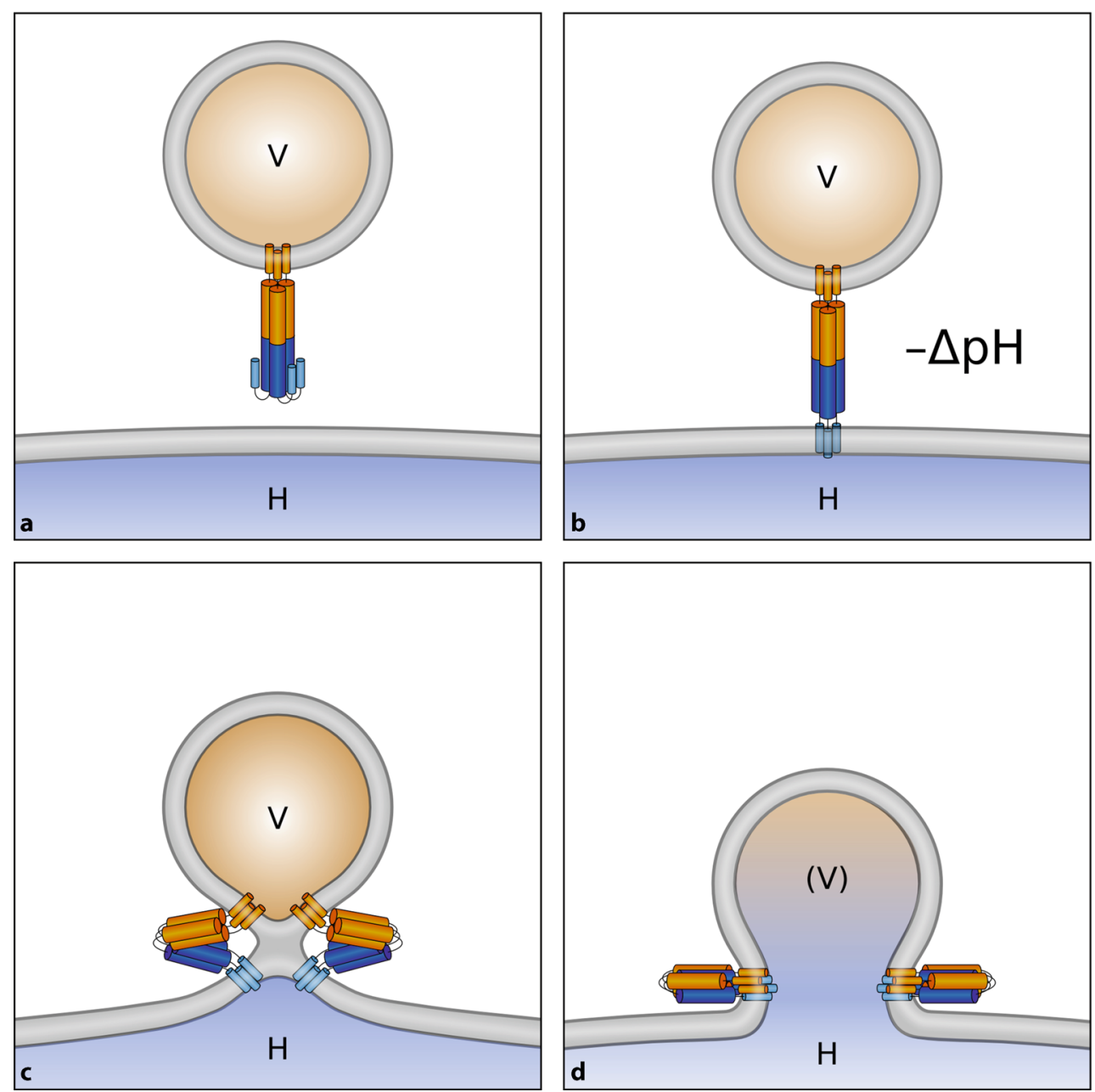

thus even fuse with the plasma membrane at neutral $\mathrm{pH}[27,28]$. In any case, a structural change of a conformationally metastable viral surface protein needs to occur; this results in exposure of a previously hidden fusion peptide, usually a stretch of amphipathic and/or hydrophobic amino acid residues. The metastable state is often prepared during maturation via cleavage of the protein, setting the trigger for this sequence to insert into the cellular membrane upon arrival in a low-pH environment. The ensuing conformational change forces the viral membrane and the cellular membrane into close apposition. The result is hemifusion (i.e., an intermediate state without content mixing), and finally the complete melding of the two membranes, including lipid mixing and delivery of the nucleocapsid into the cytosol (Fig. 1).

Whereas membrane fusion is quite well understood, penetration of naked viruses still holds a number of open questions; in principle, access of the viral genome to the cytoplasm might either occur via disruption of the virus-containing vesicle-with the entire virion, together with other endosomal content, being released into the cytosol-or via pores of limited size in the endosomal membrane. Such pores are presumably lined by domains of viral proteins forming a channel contiguous with a pore in the viral shell. The holes in the virus capsid open upon a conformational switch, again most often triggered by the acidic $\mathrm{pH}$ and sometimes assisted by the viral receptor [29]. As described in more detail at the end of this article, by using common cold viruses as examples of cellular entry by non-enveloped viruses, Renate Fuchs has been working for many years on unravelling viral uptake and trafficking of viruses inside the cell, and the transfer of the viral RNA genome into the cytosol (see reviews [30, 31]). Because at least three different receptors are used by the three rhinovirus species, it is no wonder that they enter host cells via different endocytic pathways [32-34]. As a result, uncoating, i. e., release of their positive-sense single stranded RNA genome, might occur in different cellular compartments via different mechanisms, which is the subject of the last sections of this article.

\section{Viral attachment-role and function of the receptors}

Parameters governing interactions between viruses and their cognate receptors have been investigated in vitro mostly by surface plasmon resonance method- 
ology, for an example, see [35]. Virus is immobilized on a dextran-modified metal surface, a solution containing recombinant soluble receptor (i. e., lacking the membrane anchor) is constantly flown over the chip, and binding is monitored online as a mass-dependent change of the surface plasmon resonance angle. On washing with plain buffer, previously bound receptor dissociates, returning the signal to baseline. From these binding/unbinding profiles, the on and off rates and the affinity constants can be derived.

Capillary electrophoresis was demonstrated to yield information on the number of soluble receptors bound per virion by resolving virus with zero and up to 12 attached receptors. In addition, a rough estimate of the affinity constant could be derived [36]. Here, both components are free in solution and their concentrations and those of their complexes at different stoichiometry are measured.

Atomic force microscopy can deliver a detailed energy landscape of the unbinding forces when the virus is pulled away from the receptors and the (noncovalent) bonds between them are ruptured sequentially [37-39].

Finally, information on the spatial arrangement of the five ligand-binding modules of a soluble verylow density lipoprotein receptor (VLDLR) concatemer construct on the surface of a rhinovirus could be inferred from fluorescence resonance energy transfer between its N- and C-termini. Quenching was recorded upon attachment. This demonstrated that the ends indeed come close to each other when the receptor molecules wrap around each of the vertices at the 5-fold axes of icosahedral symmetry [40].

Although providing valuable information, the experimental conditions of at least the first two methods are not representative of the in vivo situation where the receptor is anchored in the cellular membrane. In this latter context, binding of a virus to its membrane receptor is not always as straightforward; it might be preceded by relatively unspecific electrostatic interactions with charged molecules at the cell surface, such as heparan sulfate or sialic acid, either tethering the virions to the plasma membrane and thus increasing their local concentration, or rather hampering their access to the receptor(s) and thus decreasing their local concentration [41]. Such effects are difficult to investigate; live-cell single-particle tracking methods [42] have suggested that some viruses remain on the cell surface for extended periods of time wandering. According to the "seek and stick" paradigm, a virus would thus diffuse in the plane of the membrane, bound weakly and rather unspecifically to main components of the glycocalyx, such as proteoglycans, glycolipids, etc., until it encounters its specific, higher-affinity receptor(s), usually present at lower density. Single receptor molecules might cluster during this diffusion in two dimensions, as a consequence of the multivalence of the virion. This can increase the avidity of the interaction, and, at the same time, slow down the speed of diffusion, i. e., the virus would collect several receptors on this excursion. In some specific cases, such avidity effects might turn on the endocytosis machinery at a site of multivalently attached virus by relaying signals into the cell [43]. There are also other ways one can envisage the sequence of events leading to formation of a virus-receptor complex ready to be engulfed; to give just one example, the high-affinity receptors might be confined to special microdomains (e.g., lipid rafts enriched in cholesterol), requiring the virus to first arrive in such microdomains by diffusion in order for tight binding to become possible [14]. High-speed particle tracking experiments have suggested that the plasma membrane is not a two-dimensional continuum fluid, but rather contains submicron compartments with different fluidity [44]. Reminiscent of signal transduction via bi- or oligomeric natural ligand molecules, the cytoskeleton might also be involved in limiting virus movements or in relaying viral entry via signals triggered through virus-induced clustering of the membrane receptors. It must be taken into account that the number of receptor molecules simultaneously attached to a single virion might impact on efficiency and speed of the uptake, as well as on uncoating later in the entry pathway, e.g., by exerting disruptive strain. For example, uncoating of HIV-1 was shown to depend on dynein and kinesin 1 . It was suggested that these motors exert mechanical forces "tearing apart the virion" [45]. Another example is the pull of kinesin on adenovirus capsids when bound to the nuclear pore complex via Nup214 [46]. In addition, transport of receptor-bound virus to sites of active endocytosis (e.g., from filopodia to the cell body) has been observed.

\section{Uptake of the virus into the cell}

Uptake of cargo, be it for nutrition, signaling, or for downregulating signals by ferrying receptor-ligand complexes to lysosomes for degradation, can occur mainly by i) clathrin-mediated endocytosis (CME), ii) caveolin-mediated uptake (CavME), iii) macropinocytosis, and iv), poorly characterized uptake mechanisms involving neither clathrin nor caveolin. These processes are usually summarized under the name of endocytosis. It is of note that often none of these pathways is exclusively exploited by a given virus; even more so when one entry route is blocked, e.g., by a specific inhibitor. In this situation, the cell might compensate by upregulating another pathway that will then also be used by the virus [47]. By the same token, a given virus might prefer different pathways in different cells [48].

Various components of the internalization machinery can be targeted by chemical inhibitors or ablated through genetic approaches such as RNA knockdown [49]. Recently, high-throughput screening of gene knockout libraries generated via CRISPR/Cas9 allowed 
identification of factors involved in uptake of bacterial toxins [50]; obviously, the same techniques can be used to find genes involved in viral endocytosis. Nevertheless, such results are sometimes ambiguous, either because of low specificity, redundancy of the targeted factors, or because the inhibited components take part in more than one pathway. Systematic and bioinformatics-guided RNAi screens have recently been adopted to identify proteins of the host cell involved in uptake of viruses [51-53]. This method involves cell transfection with short 'interfering RNAs' with complementarity to sequences of a target mRNA to be silenced. Their hybridization results in their degradation and consequently in downregulation of the encoded protein.

Finally, haploid mutant cell libraries-with each clone having a different gene inactivated-have been prepared. Screening such libraries for reduced viral replication has led to the identification of host components essential in virus uptake and to drugs specifically inhibiting the function of these factors [54, 55]. Such cellular components are clearly less prone to escape by viral mutation and are increasingly considered as possible targets for antiviral drugs.

\section{Clathrin-mediated endocytosis}

CME (Fig. 2 pathway 1) is the by far best understood mechanism of cellular uptake (for an instructive movie see ref [56]). Many ligands (e.g., low-density lipoprotein, chylomicrons, $\mathrm{Fe}^{3+}$-saturated transferrin, growth factors, etc.) are channeled into this system via receptors whose cytoplasmic tails feature amino acid (AA) sequence motives like Asn-Pro-X-Tyr ( $\mathrm{X}$ is any $\mathrm{AA}$ ) or two consecutive leucines (the di-leucine motive) [57]. These signatures are recognized by the adapter complex AP-2 that tethers soluble clathrin monomers to the inner side of the plasma membrane for polymerization into a coat easily seen under the electron microscope. More than fifty other components are involved in CME; the membrane is curbed to build a shallow basket or pit that subsequently grows to form an invagination that becomes constricted and pinches off the plasma membrane. The main players in this process are the GTPase dynamin, the membrane-bending protein amphiphysin, and the AP-2 binding protein eps15 [58]. Finally, a clathrin-coated vesicle is formed [59]; once free in the cytosol, this coat is again removed under ATP hydrolysis, making the membrane accessible for fusion and fission with other vesicles [60]. During these maturation/fusion steps new proteins are acquired, amongst them the vesicular ATPase complex that acidifies the vesicular lumen by pumping $\mathrm{H}^{+}$into the vesicle, creating an increasingly acidic intravesicular environment and a membrane potential [26]. The endocytic vesicles move on and finally fuse with lysosomes, the disassembly and degradation factories of the cell. Thus, viruses need mechanisms to release their precious

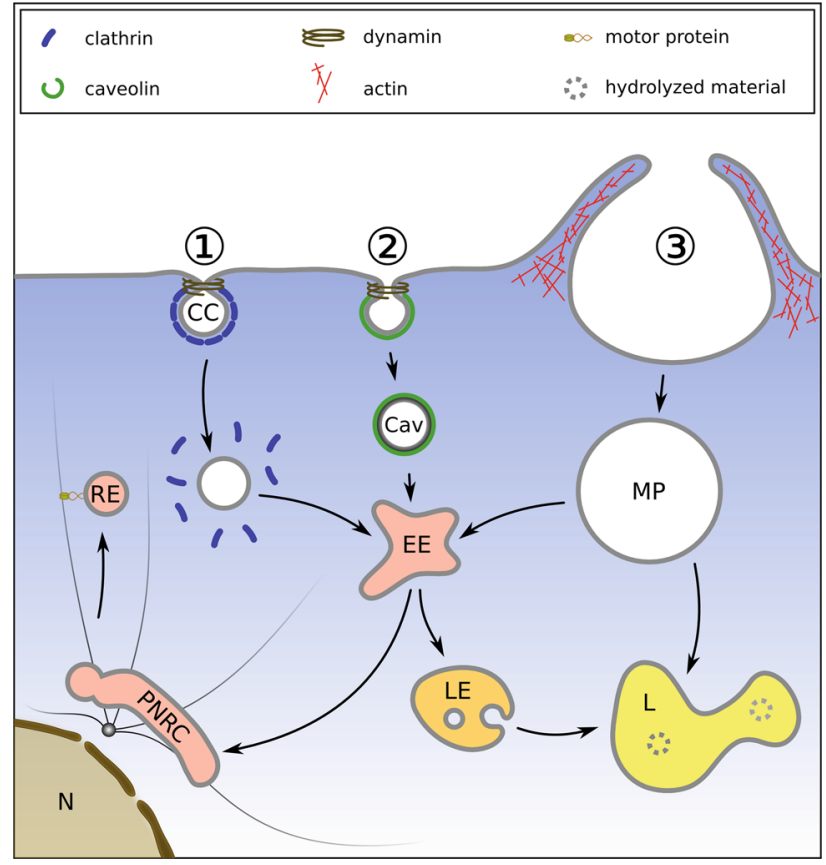

Fig. 2 Simplified view of the major entry pathways. 1 Clathrindependent endocytosis. Clathrin-coated (CC) pits are formed at the plasma membrane and mature into clathrin-coated vesicles. These are severed from the plasma membrane by dynamin that forms rings around the necks. Once inside the cytosol, the coat is removed by uncoating ATPases, making the membrane accessible for fusion with other vesicles. Maturation and fusion results in the formation of early endosomes $(E E)$; these mature further into late endosomes ( $L E)$ and/or fuse with LE. During the process, the $\mathrm{pH}$ continuously decreases from neutral to about 5.6 , depending on the cell type. LE finally fuse with lysosomes $(L)$, where the luminal content is degraded by hydrolases whose activity is maximal around $\mathrm{pH} 5$. A side step from EE leads to the perinuclear recycling compartment (PNRE). Some ligands (e. g., transferrin) are returned to the plasma membrane via recycling endosomes (RE). 2 Caveolae (Cav) feature a particular lipid composition rich in cholesterol and glycosyl phosphoinositollinked proteins, and a more translucent coat of cavin. They can be shuttled to endosomes but also to the Golgi (not shown here). 3 Macropinosomes $(M P)$ form under the direction of actin fibers and transport extracellular liquid but also membrane-bound ligands. They travel to lysosomes for fusion and degradation of their content, but there is a connection to EE as well. Vesicles are often ferried along actin fibers and microtubules via motor proteins like kinesin and dynein (as indicated for RE)

genome undamaged into the cytosol to avoid destruction at the end of this itinerary by the aggressive lysosome.

CME can be blocked by various more or less specific chemical inhibitors, amongst them chlorpromazine and dynasore, by siRNAs (small interfering RNAs, see also RNAi above) knocking down the clathrin heavy chain and/or dynamin-2 (dyn2), and by expression of a dominant-negative form of this latter protein $\left(\right.$ dyn $\left._{\mathrm{K} 44 \mathrm{~A}}\right)$ or of eps 15 lacking the modules that interact with AP2 [61]. Chlorpromazine relocates clathrin and the adaptor complex AP-2 from coated pits to vesicles [62]; dynasore, the dyngos, dynols, and the iminodyns 
are all inhibitors of dynamin's GTPase activity and, as such, target all processes involving dynamins $[63,64]$. Pitstop inhibits interaction of amphiphysin with the amino terminal domain of clathrin and was thus expected to be specific for CME. However, it appears to also affect various forms of clathrin-independent endocytosis (CIE) [65]. Other measures, like potassium depletion or incubation of the cells with hypertonic sucrose, have been shown to dissociate polymerized clathrin and thereby inhibit entry of viruses by CME [66]. So, the best way to identify the main entry pathway exploited by a given virus is via employing several of the methods mentioned above in parallel.

\section{Caveolae-mediated endocytosis (CavME)}

There are substantially fewer reports on viral entry involving caveolae than clathrin-coated pits, and only few viruses have been found to preferentially exploit this route. In addition, early reports on caveosomes, vesicles presumably derived from caveolae [67], in viral entry have been partially superseded by later results, e.g., see the case of echovirus 1 [68, 69]. Morphologically, caveolae are easily distinguishable from clathrin-coated pits; in the transmission electron microscope they show a typical elongated form reminiscent of round-bottom flasks extending into the cytosol, with a cavin coat that is less electron-dense than clathrin [70]. Their necks are open at the cell surface ([71]; Fig. 2 pathway 2). Apart from caveolin-1, a main component, caveolae possess a particular lipid composition with high cholesterol and glycosphingolipid content, and accumulate membrane proteins with glycosylphosphatidyl-anchors; as caveolae originate from cholesterol-rich lipid rafts, their lipid composition is similar. Viruses that might enter via this route include simian virus 40 (SV40), polyomavirus, echovirus 1 (but see above), certain coxsackieviruses, and some others [67]. Compared to CME, entry via caveolae is slow, i.e., the viruses might remain for hours unchanged in caveosomes, a distinct class of caveolin-1-containing endosomes identified in some cell lines. Similar to the reports on echovirus 1, SV40 entry in the absence of caveosome formation was also demonstrated. This questions the role of caveolin in the uptake of these particular viruses [72].

There are inhibitors that are, to some low extent only, specific for the caveolar pathway, such as the protein kinase inhibitor genistein. A combination of the cholesterol-sequestering drugs nystatin or filipin with the cholesterol-synthesis inhibitor progesterone blocks the formation of caveolae as summarized in [73]. Since severing of caveolae from the plasma membrane also involves dynamin, drugs blocking its function also block the caveolar pathway (see above).

\section{Macropinocytosis}

During macropinocytosis cellular protrusions are actively formed and fold back onto the plasma membrane under the direction of actin assembly (Fig. 2 pathway 3 ; [74]); the process primarily takes up liquid but also material bound to the region where the vesicles form [75]. Few viruses have been shown to definitely enter via this pathway [76]; amongst them a murine amphotropic retrovirus [77], which this was inferred from its uptake into fibroblasts lacking caveolin or dynamin. Cytochalasin and latrunculin block both macropinocytosis and actin-dependent phagocytosis that is responsible for engulfment of larger particles, such as bacteria, and were shown to also reduce entry of this virus. Amiloride acts on $\mathrm{Na}^{+} / \mathrm{H}^{+}$exchangers at the plasma membrane and has been used as a moderately specific inhibitor of macropinocytosis. At least in A431 cells it was shown to increase the submembranous $\mathrm{pH}$ that is normally lowered by metabolically generated acid; this, in turn, inhibits activation of GTPases involved in actin remodeling [78]. However, amiloride and it derivatives can also block later steps in viral synthesis, like replication of the nucleic acid; therefore, results with this drug need to be controlled with much care. The inhibitor profiles are often not exactly the same for the uptake of different viruses, making it difficult to term the process "typical" macropinocytosis. This might result from the virus exploiting other pathways in parallel to different degrees.

\section{"Virus-made invaginations"}

The unique structure of the GM1 ganglioside, which can act as an SV40 receptor, together with the multitude of binding sites on the virion can promote membrane curvature and internalization by itself, in the absence of any invagination-promoting coats. Remarkably, even long tubules containing a multitude of viruses arranged as pearls on a string were observed [79]. Similarly, virus-like particles derived from a norovirus were shown to induce negative membrane curvature on binding to glycosphinoglipids present in giant unilamellar vesicles [80]. Although different from "pure" lipid-mediated endocytosis studied in liposomes [81], a similar effect might be responsible for deep invaginations seen around a rhinovirus (RV-A2) when bound to concatemers of five copies of repeat 3 of VLDLR, recombinant high-affinity protein receptors that were attached to liposomes via a his ${ }_{6}$-tag, which, in turn, was bound to Ni-nitrilotriacetate (Ni-NTA) lipids incorporated in the lipid bilayer [82]. Clearly, all cellular components involved in membrane-bending and fission were lacking in these latter highly artificial systems and no vesicles were observed inside the liposomes; formation of these pits and tubules might be strongly dependent on concentration, affinity, and size of the receptors. Similar tubules filled with inter- 
cellular adhesion molecule 1 (ICAM-1)-binding rhinoviruses had been observed in rhabdomyosarcoma cells overexpressing this receptor [33]. It is unknown whether a similar entry mechanism operates in vivo in cells expressing the respective receptors-protein but not lipid-at high concentration.

\section{Entry of common cold viruses - a paradigm for naked virus entry}

Rhinoviruses (RVs) are the main cause of common colds. They are of enormous economic impact, estimated at about 25 billion USD per year in the USA due to absences from work, spending for medicines, and doctors' visits [83]. Infections are recurrent and often involve different RV serotypes. Nevertheless, immunization with recombinant viral proteins seems to result in antibodies more broadly cross-reacting; however, again only with low cross-neutralization efficiency [84-87]. A major challenge for production of a vaccine is the large number of different viral serotypes, which would require the formulation to contain at least one representative of each cluster of the (weakly) cross-reacting antigens, which is difficult to realize.

\section{Rhinovirus receptors}

RVs are of comparatively simple architecture; an icosahedral shell with $\mathrm{T}=1, \mathrm{P}=3$ symmetry is built from sixty copies of four different capsid proteins, VP1 through VP4, that enwrap a single-stranded positivesense RNA genome of roughly 7100 bases in length. The particle is about $30 \mathrm{~nm}$ in diameter. Within the family picornaviridae, the Enterovirus genus includes more than 150 RVs divided into three species, RV$\mathrm{A}, \mathrm{RV}-\mathrm{B}$, and RV-C. It also includes the three poliovirus serotypes, the coxsackieviruses, and the wellknown enterovirus EV71-causing epidemics of handfoot-and-mouth disease with severe complications [88]-amongst many others. Despite high similarity of the nucleotide sequence of their RNA genomes [89] and three-dimensional structures, RVs recognize three different classes of receptors; twelve RV-A use members of the low-density lipoprotein receptor (LDLR) family for cell entry and constitute the minor receptor group [90-93]. Ninety species, comprising representatives of both species $\mathrm{A}$ and $\mathrm{B}$, the major receptor group, bind ICAM-1 [94]. And finally, about fifty RV$\mathrm{C}$ might bind the cadherin-related family member 3 (CDHR3), as so far explicitly demonstrated for three representatives [89, 95, 96].

The different receptors are unrelated and exhibit different AA sequences, 3D-structures, and functions in the context of cell metabolism. Whereas LDLRs are ubiquitous and highly conserved throughout animal species, ICAM-1 is not expressed in all cell types and is less conserved; major-group RVs only bind the human and primate version of ICAM-1. Systematic humanization of the mouse protein allowed pinpointing
AA residues important for recognition [97]. The natural human ICAM-1 Kilifi variant substantially differs in affinity for RV14 and RV16 [98], allowing for estimation of the impact of a single AA mutation on virus recognition. Whereas numerous $3 \mathrm{D}$-structures of virions belonging to the major and minor receptor groups in complex with their cognate receptors are available, most of what is known on CDHR3 interaction with HRV-Cs is derived from homology modelling [99] and no 3D structure is yet available. Probably, this is due to the low yield of virus in cells transfected to express the receptor; no established cell line that would become infected by RV-Cs has been found so far.

Members of the LDLR family possess various numbers of highly conserved ligand binding modules, seven in LDLR, eight in very-LDLR (VLDLR), and 31 in LDLR-related protein (LRP) [100]. Single modules exhibit very low binding affinity; however, simultaneous binding of several modules results in a considerable increase in avidity [101, 102]. Although not anticipated in initial cryo-EM work [103], a recombinant concatemer of five copies of module 3 of VLDLR was later demonstrated to arrange around a five-fold symmetry axis of the virus in a ring-like structure [40, $104,105]$. Interestingly, binding of a recombinant concatemer (i.e., five identical repeats fused head to tail) of repeat 3 of VLDL neutralized infectivity not only via competition with the natural receptor, but also via inhibiting the structural changes necessary for the release of the RNA [102, 106, 107]. Mutations of single VLDLR modules and their display on phage [108], as well as systematic exchange of human LDLR repeats for their mouse homologues [109] allowed the requirements of particular AA residues for viral recognition to be defined. The different modules in LDLR and LRP exhibit various degrees of affinity; therefore, they most likely contribute to the overall binding avidity to a different extent. The footprint of the receptor modules indicates that the interactions are mostly governed by charge and shape complementarity [90, 105, 110]. Since VLDLR is probably not expressed in the nasal mucosa $[111,112]$, presumably only LDLR and LRP are used by minor-group RVs for cell entry and infection in vivo [92]. In contrast to ICAM-1 (see below), LDLRs merely function as vehicles for virus entry. However, they might have a role in release of the virus from its receptors in the late endosomal compartment through the $\mathrm{pH}$-dependence of the binding affinity [113].

LDLR molecules wrap around each of the 12 starlike mesas at the five-fold axes by engaging several, presumably up to five, ligand-binding repeats [104, 105]. In LRP, the 31 repeats are arranged in groups with spacers in between. Thus, it is possible that LRP can bind simultaneously to more than one pentamer because of its length. At maximal occupancy the stoichiometry (virus: soluble receptor) is $1: 12$ for recombinant VLDLR and, presumably, LDLR [113-116], but maybe less for LRP. 
ICAM-1, the receptor of major-group RVs [117], belongs to the immunoglobulin (Ig) superfamily and has five Ig-domains [118], with only the first one (D1) being engaged in RV binding [119]; the second domain appears to be necessary for correct folding of D1. Cryo-EM reconstructions of complexes between representative RVs and soluble ICAM-1 show the latter sticking out from the canyon, upright with a slight outward inclination [120]. The theoretical stoichiometry at maximal occupation is 1:60 for ICAM-1 [121].

According to the canyon hypothesis, receptorrecognizing $\mathrm{AA}$ residues would be inaccessible for antibodies due to the narrowness of the canyon [122, 123]. Nevertheless, at least one monoclonal antibody (MAb) reaching far into this valley has been isolated. The paratopes of IgG molecules and of ICAM-1 are quite different and AA residues recognized by the MAb differ from those recognized by ICAM-1. This allows for escape from antibody neutralization via mutation without substantially changing receptor binding [124]. This also explains why ICAM-1 binds many different RVs, whereas MAbs targeting residues at the canyon floor and cross-reacting with several RV serotypes have not been described. On the other hand, for minor-group viruses, the receptor-binding site is entirely exposed and available for antibody recognition. Again, no cross-reacting antibodies targeting residues within the receptor footprint have been reported; in this case, this might be due to the necessity to bind more than one symmetrically-related site for appreciable avidity, which is impossible for IgGs because of their lower valence, geometry, and steric constraints. It has not been addressed whether IgMs, which would at least allow pentavalent attachment to such sites, might be better cross-reactors, assuming that the geometry and flexibility would allow such interactions.

A particular feature of ICAM-1 is its "catalytic" activity; in vitro, interaction with cognate RVs at a temperature above $30{ }^{\circ} \mathrm{C}$ leads in some, but not all, major-group RVs to uncoating at neutral $\mathrm{pH}$, a process remotely similar to catalysis [121, 125-127]. Since initial low-affinity binding is followed by an increase in affinity it is likely that the receptor stabilizes an "open" conformation temporarily adopted by the virus via "breathing" [127]. This might allow ICAM-1 to penetrate more deeply into the canyon [128]. Breathing is also responsible for the transient exposure of capsidinternal protein sequences at the N-terminus of VP1 and the myristoylated VP4 that are not accessible at lower temperature $[129,130]$. Thus, ICAM-1 can be seen as a wedge driven into the canyon just when it is expanded. This would shift the equilibrium between the two conformations towards the more "open" one. The "priming" for uncoating strongly depends on the temperature and the concentration of soluble ICAM-1, which agrees with the dynamic structural rearrangements [131, 132]. However, receptor-driven uncoating is not very efficient at neutral $\mathrm{pH}$ but is aided by acidification [133]. RV-A89 adapted to grow in cells devoid of ICAM-1 was more readily neutralized by soluble ICAM-1. This might indicate that a decrease in stability is necessary for becoming less dependent, and finally independent-like minor-group RVs - from the destabilizing activity of ICAM-1 and allowing the use of a receptor that "just binds but does not uncoat" [134]. The concentration range of soluble ICAM-1 required for $50 \%$ neutralization of different serotypes at physiologic $\mathrm{pH}$ extends over about 1.7 logs [135]; whether competition with the cellular receptor or ICAM-1-catalyzed uncoating is primarily responsible for neutralization cannot be inferred from these simple measurements. It is noteworthy that dimerization of the ICAM-1 molecule increases its neutralization potency [136], which might be a mechanical phenomenon resulting from generation of strain upon bivalent binding with suboptimal geometry. The "hit-and-run" uncoating of poliovirus [137] and EV71 by monoclonal antibodies [138] might be related phenomena.

The ratio between the number of physical rhinovirus particles and the number of infectious particles is in the range of 24-240 under mild purification conditions using metrizamide density gradients, and can be much higher when harsh conditions such as CsCl-gradient centrifugation are used [94]. It is not known whether this ratio is lower for unpurified virus. It is thus necessary to not only follow the physical particles on their way into the cell but also to demonstrate that a given pathway leads to initiation of infection. Therefore, it is essential to assess "productive" infection as well. Preferentially, such assays should target an early stage of the viral replication cycle to avoid secondary effects of inhibitors and/or particular experimental incubation conditions on later stages such as RNA replication, assembly, maturation, and release of progeny. Considering that i) uncoating results in release of the viral RNA into the cytosol, that ii) this RNA is translated, and that iii) the resulting polyprotein is cleaved to release the 2A protease, which, in turn, cleaves the eukaryotic initiation factor $4 \mathrm{G}$ (eIF4G), the latter can be correlated with uncoating. The more RNA arrives in the cytosol the more eIF4G is cleaved. The tiny amounts of the viral proteinase P2A that becomes translated from the incoming viral RNA have thus been used to demonstrate viral uncoating without having to wait until replication has set in [33].

\section{Uptake and uncoating of the minor receptor- group prototype RV-A2}

LDLR and LDLR-related protein 1 (LRP1) possess internalization sequence motives in their $\mathrm{N}$-terminal cytoplasmic tails that typically associate with the AP-2 complex, which, in turn, assembles the clathrin coat at the cytoplasmic side of the plasma membrane giving rise to clathrin-coated pits. Indeed, uptake of the minor receptor-group prototype RV-A2 into HeLa-H1 


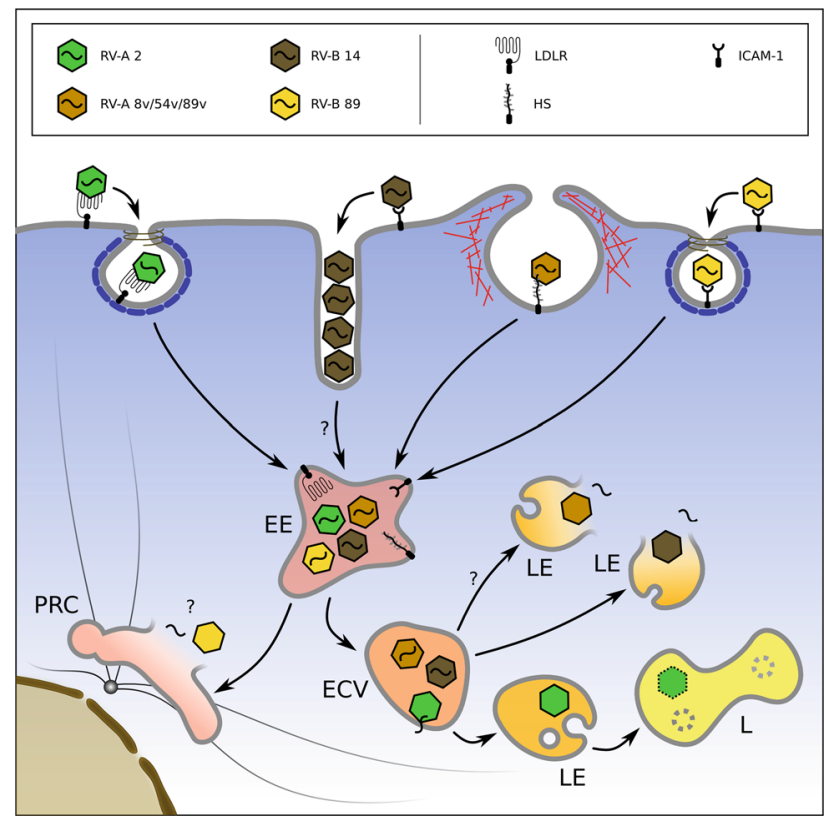

Fig. 3 Simplified view of the entry of major receptor-group rhinoviruses binding ICAM-1 (RV-B14, RV-A89), the minor receptor-group rhinovirus binding LDLR (RV-A2), and the heparan sulfate-binding variant of the major-group virus RV-A8v. On attaching to their respective receptors, RV-A2 and RV-A89 are taken up into coated and RV-B14 and RV-A8v into non-coated vesicles and tubules. RV-A2 is shuttled to early endosomes where the $\mathrm{pH}$ is about 5.8 in HeLa cells. On further acidification to a $\mathrm{pH}$ below 5.7, RV-A2 releases the RNA through a pore and the remaining capsid proteins are transferred to lysosomes for degradation. RV-A8v enters by a pathway not involving clathrin in macropinocytic vesicles but also tubules (not shown); whether it releases its RNA through holes in the membrane or via lysis of the endosomes is not known. RV-B14 lyses the endosomal membrane and RNA, as well as viral protein, arrives in the cytosol. In this case, no lysosomal degradation is observed. RV-A89 travels to recycling endosomes for uncoating, whether it disrupts the endosomes is not known. LDLR low-density lipoprotein receptor, ICAM-1 intercellular adhesion molecule 1, EL early endosome, $L L$ late endosome, $P N R C$ perinuclear recycling compartment

cells was demonstrated to be impeded by most inhibitors and interventions generally accepted to block CME, as summarized in Tab. 1 and Fig. 3. However, as mentioned above, endocytosis of RV-2A was also seen to be diverted to a non-clathrin-dependent route when the former pathway was curtailed by overexpression of the dominant negative dynamin 1 mutant K44A [139]. So, at least in HeLa-H1 (and in Rhabdomyosarcoma cells), RV-A2 primarily, but not exclusively, enters via clathrin-dependent endocytosis [33, 140].

Once inside endosomal carrier vesicles (ECV) or late endosomes, RV-A2 is believed to dissociate from its receptor, a process partly promoted by the aciddependent intramolecular competition of the betapropeller domain of LDLR with the bound virus for the ligand binding domains [114, 115] and partly by the conversion of the native virus into the expanded
A-particle that lacks affinity for the receptor. Both effects occur at about pH 5.7, usually attained in ECVs and late endosomes, depending on the cell type [113, 141, 142], and are inhibited when the $\mathrm{pH}$ is increased by incubation with weak bases, proton carriers, and inhibitors of $\mathrm{H}^{+}$-ATPases [133, 143-145]. The affinity for the receptor is lost because of the altered conformation of the subviral particle within the receptor footprint $[146,147]$. Presumably the particle is handed over to the membrane during its formation, a process assisted by the myristoylated VP4 and N-terminal sequences of VP1 both exiting from the virion and inserting into the lipid bilayer creating pores lined by amphiphilic segments of these proteins [148, 149]. Flickering pores were detected by electrophysiological measurements in experiments with the related poliovirus [150-152] and with RVA2 [30], and via the release of co-internalized FITCdextran [153]. The amount of the dextran leaking from virus-containing endosomes into the cytosol was found to be inversely proportional to its size; whereas $10 \mathrm{kD}$ dextran exited, $70 \mathrm{kD}$ dextran did not. The membrane-disrupting adenovirus used as a control released both dextrans equally well. This led the authors to conclude that RV-A2 indeed formed pores in the endosomal membrane and that the RNA genome was most likely passed through such a pore into the cytosol. These results were supported by in vitro data demonstrating that the viral RNA could be transferred from membrane-bound virions into liposomes on acidification, and that the process was accompanied by membrane permeabilization but not disruption; the maximum RNA transfer occurred at a virus concentration that only marginally impacted on membrane integrity, again speaking for RNA transfer through pores of limited size [82]. Finally, in vivo, RVA2 capsid proteins are readily degraded in lysosomes, indicating that the virus shell does not attain the cytosol. Proteolysis starts quite early; at about $30 \mathrm{~min}$ post infection, all of VP1 and a large proportion of VP2 had been cleaved [144]. Degradation of VP1 is inhibited by the microtubule-disrupting drug nocodazole, which blocks transport from ECV to lysosomes but leaves infection unaltered [143]. Nevertheless, it is possible that, similar to calicivirus infection [154], a marginal and thus difficult-to-detect cleavage of the subviral shell already occurs in (late) endosomes and facilitates RNA release in vivo.

Recently, it was demonstrated that RNA exit starts from the $3^{\prime}$-end on heating to $56^{\circ} \mathrm{C}$ in vitro [155], as well as on physiologic endosomal acidification in vivo [156]. Interestingly, upon acidification in vitro, exit halted after about 700 bases had egressed. A similar phenomenon was seen in vivo; after conversion of the native virion into the subviral A-particle, which was observed at about $5 \mathrm{~min}$ post infection at $34^{\circ} \mathrm{C}$, it took about 10 more minutes until the $7003^{3}$-terminal bases became accessible to added nuclease; at lower temperature these times were prolonged. How- 
Tab. 1 Compilation of data referenced in the text. Upper panel, impact of pharmacological inhibitors, overexpression of dominant negative mutant proteins, or other manipulations on viral entry either tested via immunofluorescence microscopy (IFM) or cleavage of elF4G and/or replication by wildtype RVs and variants binding heparan sulfate, as exemplified by RV-A8v. Note that the inhibitors of proton carriers and weak bases increasing the $\mathrm{pH}$ in endosomes - such as niclosamide, monensin, methylamine, etc. - inhibit uncoating of minor-group RVs strongly and of some major-group RVs weakly. Lower panel, colocalization of viruses with various markers observed by fluorescence microscopy. For a list on the mode of action of these inhibitors see [49]

\begin{tabular}{|c|c|c|c|c|c|c|}
\hline \multirow{2}{*}{$\begin{array}{l}\text { Serotype/receptor group } \\
\text { Process inhibited/tested via }\end{array}$} & \multicolumn{2}{|c|}{ RV-A2/minor-group } & \multicolumn{2}{|c|}{$\begin{array}{l}\text { RV-B14 (major-group), entering via } \\
\text { ICAM-1 }\end{array}$} & \multicolumn{2}{|c|}{$\begin{array}{l}\text { RV-A8v \& other major-group entering via } \\
\text { HS }\end{array}$} \\
\hline & $\begin{array}{l}\text { Entry (obs. via } \\
\text { IFM) }\end{array}$ & $\begin{array}{l}\text { elF4G clv./ } \\
\text { replication }\end{array}$ & $\begin{array}{l}\text { Entry (obs. via } \\
\text { IFM) }\end{array}$ & $\begin{array}{l}\text { elF4G clv./ } \\
\text { replication }\end{array}$ & $\begin{array}{l}\text { Entry (obs. via } \\
\text { IFM) }\end{array}$ & elF4G clv./replication \\
\hline \multicolumn{7}{|l|}{ Inhibitor } \\
\hline Chlorpromazine & Not done & Strong & Not done & Marginal & Not done & No \\
\hline Filipin or nystatin & Not done & No & Not done & No & Not done & No \\
\hline Methyl-ß-cyclodextrin & Strong & Weak & Not done & Weak & Not done & Weak \\
\hline Amiloride or EIPA & No & Strong & Not done & Strong & Not done & Strong \\
\hline Dynasore & Strong & Strong & No & Weak & Not done & Strong \\
\hline Cytochalasin D & No & Weak & Not done & Weak & Not done & Strong \\
\hline Bafilomycin & No & Strong & Not done & Weak & Not done & Not done \\
\hline Amphi-SH3 & Strong & Not done & No & Not done & No & Not done \\
\hline AP180-C & Strong & Not done & No & Not done & No & Not done \\
\hline DynK44A & Strong & Not done & No & Not done & Strong & Not done \\
\hline K-depletion & Strong & Not done & Not done & Not done & Not done & Not done \\
\hline Rab5 S34N & Strong & Not done & Not done & Not done & Not done & Not done \\
\hline \multicolumn{7}{|l|}{ Colocalization with } \\
\hline Transferrin & Weak & Not done & No & Not done & No & Not done \\
\hline Flotillin-1 & Not done & Not done & No & Not done & No & Not done \\
\hline CtxB & Not done & Not done & No & Not done & No & Not done \\
\hline FITC-dextran & Not done & Not done & Strong & Not done & Strong & Not done \\
\hline GFP-clathrin & Not done & Not done & Not done & Not done & No & Not done \\
\hline Caveolin-1 & No & Not done & Not done & Not done & No & Not done \\
\hline
\end{tabular}

ever, all the remaining genome sequences were lost from the viral shell at $34{ }^{\circ} \mathrm{C}$ within the next $2 \mathrm{~min}$. It was also found that the partial egress in vitro quickly completed when a microsomal fraction prepared from HeLa cells was added. This suggests that cellular facilitators of the process might exist. Nevertheless, it remains enigmatic how an RNA molecule with a highly complex secondary structure with many stems, loops, and hairpins, should unfold to pass through a hole of about $0.1 \times 0.2 \mathrm{~nm}$ in the absence of energy consumption in this short time.

\section{Uptake and uncoating of the major receptor- group prototype RV-B14}

ICAM-1 lacks a clathrin localization signal but its cytoplasmic tail associates with alpha-actinin, thus connecting it to the cytoskeleton [157]. However, this association is not required for viral uptake since the tail and the transmembrane region can be replaced with a glycosylphosphatidyl anchor without impact on viral infection [158]. Therefore, it is not unexpected that chlorpromazine, which is moderately specific for the clathrin-dependent pathway, and some dominant negative mutant proteins involved in clathrin-dependent endocytosis failed to block RV-B14 uptake (Tab. 1 and [33]). A particularly striking observation was the accumulation of virions in long tubules connected to the cell surface in RD and BHK-cells expressing human ICAM-1 [33, 159]. Such aggregates had not been reported for viruses internalized by clathrin-dependent endocytosis, but were observed during entry of SV40 when bound to the lipid receptor GM1 ([79] and see above); nevertheless, in some instances, RVB14 in vesicles with a coat looking very similar to a clathrin coat were seen in HeLa cells [159]. The significance of this observation for viral uptake is unclear. Entry was strongly reduced by the $\mathrm{Na}(+) / \mathrm{H}(+)$ ion exchange inhibitor amiloride, and moderately reduced by the actin polymerization inhibitor cytochalasin. Thus, it is highly likely that RV-B14 enters by a non-clathrin- non-caveolin-dependent pathway resembling macropinocytosis. Entry is slower than that of RV-A2 and a large fraction of the virus appears to be retained at the plasma membrane despite of "normal" infection efficiency. As mentioned above, RV-B14 probably arrives in the cytoplasm as a whole (subviral) particle by disruption of the endosome [153, 
160]; this contention was also supported by the finding that RV-B14 promotes endosomal release of transfection complexes [161]. In summary, RV-B14 enters via a pathway similar but not identical to typical macropinocytosis (Fig. 3).

\section{Uptake and uncoating of major receptor-group} viruses adapted to heparan sulfate proteoglycan

Identical to RV-B14, the serotypes RV-A8, RV-A54, and RV-A89 all depend on ICAM-1 for entry and are thus major-group RV [32]. The latter three were adapted to use heparan sulfate (HS) as a receptor via blind passages alternating between HeLa and (ICAM-1-negative) Hep-2 cells. RV-A89 needed 34 such passages [134, 162], RV-A8 three [32], and RV-A54 was found to already be naturally adapted [34]. In all cases, binding to ICAM-1 was not lost but the viruses had become less resistant to moderately acidic $\mathrm{pH}$. This suggests that in the absence of the "catalytic" activity of the receptor, the low $\mathrm{pH}$ alone must suffice for uncoating. HS-binding variants were shown to strictly depend on dynamin but not on clathrin, caveolin, and flotillin, as summarized in Tab. 1 for the HS-adapted variant RVA8v, whose pathway was more extensively characterized; the same profile is probably seen with the other HS-adapted variants. The tabulated data show that entry via HS is similarly, but not identically sensitive to inhibitors and manipulations as entry via ICAM1. Accumulation of the virions in tubules connected to the plasma membrane was also observed [32]. Recent work on uptake of wildtype RV-A89 (Conzemius et al. manuscript submitted) indicates that this majorgroup RV might involve clathrin for entry and uncoat in the endosomal recycling compartment (Fig. 3).

\section{Conclusion}

Similar to the natural ligands of LDLR, minor-group RVs follow the clathrin-dependent pathway for entry. Once inside endosomal carrier vesicles or late endosomes, the low-pH environment triggers conversion of the native virion into the A-particle, from which, in a poorly-understood process, the RNA is extruded through the endosomal membrane into the cytosol. Major-group ICAM-1 binding viruses appear to be taken up via a somewhat untypical form of macropinocytosis. Both pathways converge in early endosomes and the viruses are further shuttled to late endosomes. Aided by the destabilizing activity of ICAM-1 they are converted into A-particles with concomitant disruption of the endosomal membrane, releasing the subviral particle or the empty particle together with already uncoated RNA into the cytosol. Finally, HS-adapted RVs follow a very similar pathway but behave similar to minor-group RVs in being stringently dependent on low $\mathrm{pH}$ for uncoating of the viral genome. Repeated attempts to adapt a major-group virus to use LDLR as a receptor failed. This indi- cates that recognition of LDLR is not limited to mere attraction of opposite charges. On the other hand, the ubiquitous HS can be exploited for attachment and entry but, at least in vivo, there must be other more stringent requirements for not using it in nature. The future might hold surprises regarding how RV$\mathrm{C}$ viruses are taken up by CDHR3 and routed inside the host cell. Knowledge of how viruses enter the cell and points of possible intervention is of paramount importance for finding new ways of blocking infection with drugs. Cellular targets are increasingly considered for this purpose as this minimizes resistance via viral mutation.

Acknowledgements Open access funding provided by Medical University of Vienna.

Much of the research cited by the author is the product of a long, intense, fruitful, and pleasant collaboration with Renate Fuchs. It has been funded over the years by a number of individual grants from the Austrian Science Fund (FWF) to Renate Fuchs and to the author. I express my gratitude to Heinrich Kowalski and Sofiya Fedosyuk for critically reading the manuscript, and to Alexander Otahal for drawing the figures.

\section{Compliance with ethical guidelines}

Conflict of interest D. Blaas states that there are no conflicts of interest.

Ethical standards This article does not include studies on humans or animals.

Open Access This article is distributed under the terms of the Creative Commons Attribution 4.0 International License (http://creativecommons.org/licenses/by/4.0/), which permits unrestricted use, distribution, and reproduction in any medium, provided you give appropriate credit to the original author(s) and the source, provide a link to the Creative Commons license, and indicate if changes were made.

\section{References}

1. Goncalvez AP, Engle RE, Claire StM, Purcell RH, Lai CJ. Monoclonal antibody-mediated enhancement of dengue virus infection in vitro and in vivo and strategies for prevention. Proc Natl Acad Sci USA. 2007;104(22):9422-27.

2. Jiang J, Wu X, Tang H, Luo G. Apolipoprotein E mediates attachment of clinical hepatitis $\mathrm{C}$ virus to hepatocytes by binding to cell surface heparan sulfate proteoglycan receptors. PloS One. 2013;8(7):e67982.

3. Meertens L, Carnec X, Lecoin MP, Ramdasi R, GuivelBenhassine F, Lew E, et al. The TIM and TAM families of phosphatidylserine receptors mediate dengue virus entry. Cell Host Microbe. 2012;12(4):544-57.

4. Schneider-Schaulies J. Cellular receptors for viruses: links to tropism and pathogenesis. J Gen Virol. 2000; 81(6):1413-29.

5. Vasiljevic S, Beale EV, Bonomelli C, Easthope IS, Pritchard LK, Seabright GE, et al. Redirecting adenoviruses to tumour cells using therapeutic antibodies: Generation of a versatile human bispecific adaptor. Mol Immunol. 2015;68(2A):1413-29. 
6. Izmailyan R, Hsao JC, Chung CS, Chen CH, Hsu PW, Liao CL, et al. Integrin betal mediates vaccinia virus entry through activation of PI3K/Akt signaling. J Virol. 2012;86(12):6677-87.

7. Vaughan JC, Brandenburg B, Hogle JM, Zhuang X. Rapid actin-dependent viral motility in live cells. Biophys J. 2009;97(6):1647-56

8. Dodding MP, Way M. Coupling viruses to dynein and kinesin-1. EMBOJ.2011;30(17):3527-39.

9. Tan SC, Scherer J, Vallee RB. Recruitment of dynein to late endosomes and lysosomes through light intermediate chains. MolBiol Cell. 2011;22(4):467-77.

10. Garten W, Braden C, Arendt A, Peitsch C, Baron J, Lu Y, et al. Influenza virus activating host proteases: Identification, localization and inhibitors as potential therapeutics. Eur JCell Biol. 2015;94(7-9):375-83.

11. Banerjee M, Johnson JE. Activation, exposure and penetration of virally encoded, membrane-active polypeptides during non-enveloped virus entry. Curr Protein Pept Sci. 2008:9(1):16-27.

12. SuikkanenS, Antila M, Jaatinen A, Vihinen-Ranta M, Vuento M. Release of canine parvovirus from endocytic vesicles. Virology. 2003;316(2):267-80.

13. Luisoni S, Suomalainen M, Boucke K, Tanner LB, Wenk MR, Guan XL, et al. Co-option of Membrane Wounding Enables Virus Penetration into Cells. Cell Host Microbe. 2015;18(1):75-85.

14. Boulant S, Stanifer M, Lozach PY. Dynamics of virusreceptor interactions in virus binding, signaling, and endocytosis. Viruses. 2015;7(6):2794-815.

15. Barrow E, Nicola AV, Liu J. Multiscale perspectives of virus entry via endocytosis. Virol J.2013;10(1):177.

16. Sun Y, Tien P. From endocytosis to membrane fusion: emerging roles of dynamin in virus entry. Crit Rev Microbiol. 2013;39(2):166-79.

17. Schelhaas M. Come in and take your coat off - how host cells provide endocytosis for virus entry. Cell Microbiol. 2010;12(10):1378-88.

18. Mercer J, Schelhaas M, Helenius A. Virus entry by endocytosis. Annu Rev Biochem. 2010;79:803-33.

19. Yamauchi Y, Helenius A. Virus entry at a glance. J Cell Sci. 2013;126(6):1289-95.

20. Grove J, Marsh M. The cell biology of receptor-mediated virus entry. JCell Biol. 2011;195(7):1071-82.

21. Suomalainen M, Greber UF. Uncoating of non-enveloped viruses. Curr Opin Virol. 2013;3(1):27-33.

22. Endocytosis. In: Schmid SL, Sorkin A, Zerial M, editors. Cold Spring Harbor Perspectives in Biology: Cold Spring Harbor Laboratory Press; 2015.

23. Yamauchi Y, Greber UF. Principles of Virus Uncoating: Cues and the Snooker Ball. Traffic. 2016; doi:10.1111/tra.12387.

24. Schmid S, Fuchs R, Kielian M, Helenius A, Mellman I. Acidification of endosome subpopulations in wildtype Chinese hamster ovary cells and temperaturesensitive acidification-defective mutants. J Cell Biol. 1989;108(4):1291-300.

25. Fuchs R, Schmid S, Mellman I. A possible role for $\mathrm{Na}+, \mathrm{K}+-$ ATPase in regulating ATP-dependent endosome acidification. Proc Natl Acad Sci USA. 1989;86(2):539-43.

26. Mellman I, Fuchs R, Helenius A. Acidification of the endocytic and exocytic pathways. Annu Rev Biochem. 1986;55:663-700

27. Melikyan GB. HIV entry: a game of hide-and-fuse? Curr Opin Virol. 2014;4:1-7.

28. Nicola AV, Straus SE. Cellular and viral requirements for rapid endocytic entry of herpes simplex virus. J Virol. 2004;78(14):7508-17.
29. Strauss M, Filman DJ, Belnap DM, Cheng N, Noel RT, Hogle JM. Nectin-like interactions between poliovirus and its receptor trigger conformational changes associated with cell entry. JVirol. 2015;89(8):4143-57.

30. Fuchs R, Blaas D. Productive entry pathways of human rhinoviruses. Adv Virol. 2012;2012:826301.

31. Fuchs R, Blaas D. Uncoating of human rhinoviruses. Rev MedVirol. 2010;20(5):281-97.

32. Khan AG, Pickl-Herk A, Gajdzik L, Marlovits TC, Fuchs R, Blaas D. Entry of a heparan sulphate-binding HRV8 variant strictly depends on dynamin but not on clathrin, caveolin, and flotillin. Virology. 2011;412(1):55-67.

33. Khan AG, Pickl-Herk A, Gajdzik L, Marlovits TC, Fuchs R, Blaas D. Human rhinovirus 14 enters rhabdomyosarcoma cells expressing icam-1 by a clathrin-, caveolin-, and flotillin-independent pathway. JVirol. 2010;84(8):3984-92.

34. Khan AG, PichlerJ, RosemannA, Blaas D. Human rhinovirus type 54 infection via heparan sulfate is less efficient and strictly dependent on low endosomal pH. J Virol. 2007;81(9):4625-32.

35. Xing L, Tjarnlund K, Lindqvist B, Kaplan GG, Feigelstock D, Cheng RH, et al. Distinct cellular receptor interactions in poliovirus and rhinoviruses. EMBO J. 2000;19(6):1207-16.

36. Konecsni T, Kremser L, Snyers L, RanklC, Kilar F, Kenndler E, et al. Twelve receptor molecules attach per viral particle of human rhinovirus serotype 2 via multiple modules. FEBS Lett. 2004;568(1-3):99-104.

37. Sieben C, Kappel C, Zhu R, Wozniak A, Rankl C, Hinterdorfer $\mathrm{P}$, et al. Influenza virus binds its host cell using multiple dynamic interactions. Proc Natl Acad Sci USA. 2012;109(34):13626-31.

38. Rankl C, Wildling L, Neundlinger I, Kienberger F, Gruber H, Blaas D, et al. Determination of the kinetic on- and offrate of single virus-cell interactions. Methods Mol Biol. 2011;736:197-210.

39. Rankl C, Kienberger F, Wildling L, Wruss J, Gruber HJ, Blaas D, et al. Multiple receptors involved in human rhinovirus attachment to live cells. Proc Natl Acad Sci USA. 2008;105(46):17778-83.

40. Wruss J, Pollheimer, Meindl I, Reichel A, Schulze K, Schofberger W, et al. Conformation of receptor adopted upon interaction with virus revealed by site-specific fluorescence quenchers and FRET analysis. JAm Chem Soc. 2009;131(15):5478-82.

41. Mateo M, Generous A, Sinn PL, Cattaneo R. Connections matter-how viruses use cell-cell adhesion components. JCell Sci. 2015;128(3):431-9.

42. Brandenburg B, Lee LY, Lakadamyali M, Rust MJ, Zhuang X, Hogle JM. Imaging poliovirus entry in live cells. PLoS Biol. 2007;5(7):e183.

43. Greber UF. Signalling in viral entry. Cell Mol Life Sci. 2002;59(4):608-26.

44. Kusumi A, Nakada C, Ritchie K, Murase K, Suzuki K, Murakoshi H, et al. Paradigm shift of the plasma membrane concept from the two-dimensional continuum fluid to the partitioned fluid: high-speed single-molecule tracking of membrane molecules. Annu Rev Biophys Biomol Struct. 2005;34:351-78.

45. Lukic Z, Dharan A, Fricke T, Diaz-Griffero F, Campbell EM. HIV-1 uncoating is facilitated by dynein and kinesin 1 . JVirol. 2014;88(23):13613-25.

46. Strunze S, Engelke MF, Wang IH, Puntener D, Boucke K, Schleich S, et al. Kinesin-1-mediated capsid disassembly and disruption of the nuclear pore complex promote virus infection. Cell Host Microbe. 2011;10(3):210-23.

47. Bayer N, Schober D, Huttinger M, Blaas D, Fuchs R. Inhibition of clathrin-dependent endocytosis has multiple 
effects on human rhinovirus serotype 2 cell entry. J Biol Chem. 2001;276(6):3952-62.

48. Garcin PO, Pante N. The minute virus of mice exploits different endocytic pathways for cellular uptake. Virology. 2015;482:157-66.

49. DuttaD, DonaldsonJG. Search for inhibitors ofendocytosis: Intended specificity and unintended consequences. Cell Logist. 2012;2(4):203-8.

50. Zhou Y, Zhu S, Cai C, Yuan P, Li C, Huang Y, et al. High-throughput screening of a CRISPR/Cas9 library for functional genomics in human cells. Nature. 2014;509(7501):487-91.

51. Perreira JM, Aker AM, Savidis G, Chin CR, McDougall WM, Portmann JM, et al. RNASEK Is a V-ATPase-Associated Factor Required for Endocytosis and the Replication of Rhinovirus, Influenza A Virus, and Dengue Virus. Cell Rep. 2015;12(5):850-63.

52. Hackett BA, Yasunaga A, Panda D, Tartell MA, Hopkins KC, Hensley SE, et al. RNASEK is required for internalization of diverse acid-dependent viruses. Proc Natl Acad Sci USA. 2015;112(25):7797-802.

53. Ramo P, Drewek A, Arrieumerlou C, Beerenwinkel N, BenTekaya H, Cardel B, et al. Simultaneous analysis of largescale RNAi screens for pathogen entry. BMC Genomics. 2014;15:1162.

54. Essletzbichler P, Konopka T, Santoro F, Chen D, Gapp BV, Kralovics R, et al. Megabase-scale deletion using CRISPR/Cas9 to generate a fully haploid human cell line. Genome Res. 2014;24(12):2059-65.

55. Burckstummer T, Banning C, Hainzl P, Schobesberger R, Kerzendorfer C, Pauler FM, et al. A reversible gene trap collection empowers haploid genetics in human cells. Nat Methods. 2013;10(10):965-71.

56. Iwasa J, Kirchhausen T. cartographers. Clathrin-mediated endocytosis. https://vimeo.com/63913620

57. Bonifacino JS, Traub LM. Signals for sorting of transmembrane proteins to endosomes and lysosomes. Annu Rev Biochem. 2003;72:395-447.

58. Gross A. Bending membranes into different shapes. Structure. 2015;23(5):803-4.

59. Xing Y, Bocking T, Wolf M, Grigorieff N, Kirchhausen T, Harrison SC. Structure of clathrin coat with bound Hsc70 and auxilin: mechanism of Hsc70-facilitated disassembly. EMBOJ. 2010;29(3):655-65.

60. Sousa R, Lafer EM. The role of molecular chaperones in clathrin mediated vesicular trafficking. Front Mol Biosci. 2015;2:26.

61. Benmerah A, Poupon V, Cerf-Bensussan N, Dautry-Varsat A. Mapping of Eps 15 domains involved in its targeting to clathrin-coated pits. JBiol Chem. 2000;275(5):3288-95.

62. Wang LH, Rothberg KG, Anderson RG. Mis-assembly of clathrin lattices on endosomes reveals a regulatory switch for coated pitformation. JCell Biol. 1993;123(5):1107-17.

63. Robertson MJ, Deane FM, Robinson PJ, McCluskey A. Synthesis of Dynole 34-2, Dynole 2-24 and Dyngo 4 a for investigating dynamin GTPase. NatProtoc. 2014;9(4):851-70.

64. Hill TA, Mariana A, Gordon CP, Odell LR, Robertson $M J$, McGeachie AB, et al. Iminochromene inhibitors of dynamins I and II GTPase activity and endocytosis. J Med Chem. 2010;53(10):4094-102.

65. Dutta D, Williamson CD, Cole NB, Donaldson JG. Pitstop 2 is a potent inhibitor of clathrin-independent endocytosis. PloS One. 2012;7(9):e45799.

66. Vercauteren D, Vandenbroucke RE, Jones AT, Rejman J, Demeester J, Smedt SC De, et al. The use of inhibitors to study endocytic pathways of gene carriers: optimization and pitfalls. Mol Ther. 2010;18(3):561-9.
67. Pietiainen VM, Marjomaki V, Heino J, Hyypia T. Viral entry, lipid rafts and caveosomes. Ann Med. 2005;37(6):394-403.

68. Krieger SE, Kim C, Zhang L, Marjomaki V, Bergelson JM. Echovirus 1 entry into polarized Caco-2 cells depends on dynamin, cholesterol, and cellular factors associated with macropinocytosis. JVirol. 2013;87(16):8884-95.

69. Pietiainen V, Marjomaki V, Upla P, Pelkmans L, Helenius A, Hyypia T. Echovirus 1 endocytosis into caveosomes requires lipid rafts, dynamin II, and signaling events. Mol BiolCell. 2004;15(11):4911-25.

70. Kovtun O, Tillu VA, Jung W, Leneva N, Ariotti N, Chaudhary $\mathrm{N}$, etal. Structural insights into the organization of the cavin membrane coat complex. Dev Cell. 2014;31(4):405-19.

71. Shvets E, Bitsikas V, Howard G, Hansen CG, Nichols BJ. Dynamic caveolae exclude bulk membrane proteins and are required for sorting of excess glycosphingolipids. Nat Commun. 2015;6:6867.

72. Damm EM, Pelkmans L, Kartenbeck J, Mezzacasa A, Kurzchalia T, Helenius A. Clathrin- and caveolin-1-independent endocytosis: entry of simian virus 40 into cells devoid of caveolae. J Cell Biol. 2005;168(3):477-88.

73. Kiss AL. Caveolae and the regulation of endocytosis. Adv Exp Med Biol. 2012;729:14-28.

74. Mooren OL, Galletta BJ, Cooper JA. Roles for actin assembly in endocytosis. Annu Rev Biochem. 2012;81:661-86.

75. Mercer J, Helenius A. Gulping rather than sipping: macropinocytosis as a way of virus entry. Curr Opin Microbiol. 2012;15(4):490-9.

76. Mercer J, Helenius A. Virus entry by macropinocytosis. Nat Cell Biol. 2009;11(5):510-20.

77. Rasmussen I, Vilhardt F. Macropinocytosis is the entry mechanism of amphotropic murine leukemia virus. J Virol. 2015;89(3):1851-66.

78. Koivusalo M, Welch C, Hayashi H, Scott CC, Kim M, Alexander T, et al. Amiloride inhibits macropinocytosis by lowering submembranous $\mathrm{pH}$ and preventing Racl and Cdc42 signaling. JCell Biol. 2010;188(4):547-63.

79. Ewers H, Romer W, Smith AE, Bacia K, Dmitrieff S, Chai W, et al. GM1 structure determines SV40-induced membrane invagination and infection. NatCell Biol. 2010;12(1):11-8.

80. Rydell GE, Svensson L, Larson G, Johannes L, Human RWGII. 4 norovirus VLP induces membrane invaginations on giant unilamellar vesicles containing secretor gene dependent alpha1,2-fucosylated glycosphingolipids. Biochim Biophys Acta. 2013;1828(8):1840-5.

81. Ewers H, Helenius A. Lipid-mediated endocytosis. Cold Spring Harb Perspect Biol. 2011;3(8):a004721.

82. Bilek G, Matscheko NM, Pickl-Herk A, Weiss VU, Subirats $\mathrm{X}$, Kenndler E, et al. Liposomal nanocontainers as models for viral infection: monitoring viral genomic RNA transfer through lipid membranes. JVirol. 2011;85(16):8368-75.

83. Bramley TJ, Lerner D, Sames M. Productivity losses related to the common cold. J Occup Environ Med. 2002;44(9):822-9.

84. Katpally U, Fu TM, Freed DC, Casimiro DR, Smith TJ. Antibodies to the buried $\mathrm{N}$ terminus of rhinovirus VP4 exhibit cross-serotypic neutralization. JVirol. 2009;83(14):7040-8.

85. McLean GR, Walton RP, Shetty S, Peel TJ, Paktiawal N, Kebadze T, et al. Rhinovirus infections and immunisation induce cross-serotype reactive antibodies to VP1. Antiviral Res. 2012;95(3):193-201.

86. Glanville N, McLean GR, Guy B, Lecouturier V, Berry C, Girerd Y, et al. Cross-serotype immunity induced by immunization with a conserved rhinovirus capsid protein. Plos Pathog. 2013;9(9):e1003669.

87. Edlmayr J, Niespodziana K, Popow-Kraupp T, Krzyzanek V, Focke-Tejkl M, Blaas D, et al. Antibodies induced with 
recombinant VP1 from human rhinovirus exhibit crossneutralisation. Eur Respir J.2011;37(1):44-52.

88. Yip CC, Lau SK, Woo PC, Yuen KY. Human enterovirus 71 epidemics: what's next? Emerg Health Threats J. 2013;6:19780.

89. Palmenberg AC, Spiro D, Kuzmickas R, Wang S, Djikeng A, Rathe JA, et al. Sequencing and analyses of all known human rhinovirus genomes reveal structure and evolution. Science. 2009;324(5923):55-9.

90. Vlasak M, Roivainen M, Reithmayer M, Goesler I, Laine P, Snyers L, et al. The minor receptor group of human rhinovirus (HRV) includes HRV23 and HRV25, but the presence of a lysine in the VP1 HI loop is not sufficient for receptor binding. JVirol. 2005;79(12):7389-95.

91. Vlasak M, Blomqvist S, Hovi T, Hewat E, Blaas D. Sequence and structure of human rhinoviruses reveal the basis of receptor discrimination. JVirol. 2003;77(12):6923-30.

92. Hofer F, Gruenberger M, Kowalski H, Machat H, Huettinger M, Kuechler E, et al. Members of the low density lipoprotein receptor family mediate cell entry of a minorgroup common cold virus. Proc Natl Acad Sci USA. 1994;91(5):1839-42.

93. Duechler M, Ketter S, Skern T, Kuechler E, Blaas D. Rhinoviral receptor discrimination: mutational changes in the canyon regions of human rhinovirus types 2 and 14 indicate a different site of interaction. J Gen Virol. 1993;74(10):2287-91.

94. Abraham G, Colonno RJ. Many rhinovirus serotypes share the same cellular receptor. JVirol. 1984;51(2):340-5.

95. Palmenberg AC, Gern JE. Classification and evolution of human rhinoviruses. Methods Mol Biol. 2015;1221:1-10.

96. Bochkov YA, Watters K, Ashraf S, Griggs TF, Devries MK, Jackson DJ, et al. Cadherin-related family member 3, a childhood asthma susceptibility gene product, mediates rhinovirus $C$ binding and replication. Proc Natl Acad Sci USA. 2015;112(17):5485-90.

97. Register RB, Uncapher CR, Naylor AM, Lineberger DW, Colonno RJ. Human-murine chimeras of ICAM-1 identify amino acid residues critical for rhinovirus and antibody binding. JVirol. 1991;65(12):6589-96.

98. Xiao C, Tuthill TJ, Bator KCM, Challinor LJ, Chipman PR, Killington RA, et al. Discrimination among rhinovirus serotypes for a variant ICAM-1 receptor molecule. J Virol. 2004;78(18):10034-44.

99. Basta HA, Sgro JY, Palmenberg AC. Modeling of the human rhinovirus $C$ capsid suggests a novel topography with insights on receptor preference and immunogenicity. Virology. 2014;448:176-84.

100. Blacklow SC. Versatility in ligand recognition by LDL receptor family proteins: advances and frontiers. Curr Opin StructBiol. 2007;17(4):419-26.

101. Wruss J, Runzler D, Steiger C, Chiba P, Kohler G, Blaas D. Attachment of VLDL receptors to an icosahedral virus along the 5 -fold symmetry axis: multiple binding modes evidenced by fluorescencecorrelation spectroscopy. Biochemistry. 2007;46(21):6331-9.

102. Moser R, Snyers L, Wruss J, Angulo J, Peters H, Peters T, et al. Neutralization of a common cold virus by concatemers of the third ligand binding module of the VLDL-receptor strongly depends on the number of modules. Virology. 2005;338(2):259-69.

103. Hewat EA, Neumann E, Conway JF, Moser R, Ronacher B, Marlovits TC, et al. The cellular receptor to human rhinovirus 2 binds around the 5 -fold axis and not in the canyon: a structural view. EMBOJ.2000;19(23):6317-25.

104. Querol-Audi J, Konecsni T, Pous J, Carugo O, Fita I, VerdaguerN, etal. Minor group human rhinovirus-receptor interactions: geometry of multimodular attachment and basis of recognition. FEBS Lett. 2009;583(1):235-40.

105. Verdaguer N, Fita I, Reithmayer M, Moser R, Blaas D. X-ray structure of a minor group human rhinovirus bound to a fragment of its cellular receptor protein. NatStruct MolBiol. 2004;11(5):429-34

106. Nicodemou A, Petsch M, Konecsni T, Kremser L, Kenndler E, Casasnovas JM, et al. Rhinovirus-stabilizing activity of artificial VLDL-receptor variants defines a new mechanism for virus neutralization by soluble receptors. FEBS Lett. 2005;579(25):5507-11.

107. Ronacher B, Marlovits TC, Moser R, Blaas D. Expression and folding of human very-low-density lipoprotein receptor fragments: neutralization capacity toward human rhinovirus HRV2. Virology. 2000;278(2):541-50.

108. NizetS, Wruss J, Landstetter N, Snyers L, Blaas D. Amutation in the first ligand-binding repeat of the human very-lowdensitylipoprotein receptor results in high-affinity binding of the single V1 module to human rhinovirus 2. J Virol. 2005;79(23):14730-6.

109. Reithmayer M, Reischl A, Snyers L, Blaas D. Species-specific receptor recognition by a minor-group human rhinovirus (HRV): HRV serotype 1A distinguishes between the murine and the human low-density lipoprotein receptor. J Virol. 2002;76(14):6957-65.

110. Weber C, Pickl-Herk A, Khan AG, Strauss S, Carugo $\mathrm{O}$, Blaas D. Predictive bioinformatic identification of minor receptor group human rhinoviruses. FEBS Lett. 2009;583(15):2547-51.

111. Iijima H, Miyazawa M, Sakai J, Magoori K, Ito MR, Suzuki $\mathrm{H}$, et al. Expression and characterization of a very low density lipoprotein receptor variant lacking the O-linked sugar region generated by alternative splicing. J Biochem. 1998;124(4):747-55.

112. Nakamura Y, Yamamoto M, Kumamaru E. Very low-density lipoprotein receptor in fetal intestine and gastric adenocarcinoma cells. Arch Pathol Lab Med. 2000;124(1):119-22.

113. KonecsniT, Berka U, Pickl-HerkA, BilekG, KhanAG, Gajdzig $\mathrm{L}$, et al. Low pH-triggered beta-propeller switch of the lowdensity lipoprotein receptor assists rhinovirus infection. JVirol. 2009;83(21):10922-30.

114. Blacklow SC. Catching the common cold. Nat Struct Mol Biol. 2004;11(5):388-90.

115. Beglova N, Blacklow SC. The LDL receptor: how acid pulls the trigger. Trends Biochem Sci. 2005;30(6):309-17.

116. Brabec M, Baravalle G, Blaas D, Fuchs R. Conformational changes, plasma membrane penetration, and infection by human rhinovirus type 2: role of receptors and low $\mathrm{pH}$. JVirol. 2003;77(9):5370-7.

117. Greve JM, Davis G, Meyer AM, Forte CP, Yost SC, Marlor CW, et al. The major human rhinovirus receptor is ICAM-1. Cell. 1989;56(5):839-47.

118. Staunton DE, Marlin SD, Stratowa C, Dustin ML, Springer TA. Primary structure of ICAM-1 demonstrates interaction between members of the immunoglobulin and integrin supergene families. Cell. 1988;52(6):925-33.

119. Olson NH, Kolatkar PR, Oliveira MA, Cheng RH, Greve JM, McClelland A, et al. Structure of a human rhinovirus complexed with its receptor molecule. Proc Natl Acad Sci USA. 1993;90(2):507-11.

120. Xing L, Casasnovas JM, Cheng RH. Structural analysis of human rhinovirus complexed with ICAM-1 reveals the dynamics of receptor-mediated virus uncoating. J Virol. 2003;77(11):6101-7.

121. Hoover-Litty H, Greve JM. Formation of rhinovirus-soluble ICAM-1 complexes and conformational changes in the virion. JVirol. 1993;67(1):390-7. 
122. Rossmann MG. The canyon hypothesis. Hiding the host cell receptor attachment site on a viral surface from immune surveillance. J BiolChem. 1989;264(25):14587-90.

123. Colonno RJ, Condra JH, Mizutani S, Callahan PL, Davies ME, Murcko MA. Evidence for the direct involvement of the rhinovirus canyon in receptor binding. Proc Natl Acad Sci USA. 1988;85(15):5449-53.

124. Smith TJ, Chase ES, Schmidt TJ, Olson NH, Baker TS. Neutralizing antibody to human rhinovirus 14 penetrates the receptor-binding canyon. Nature. 1996;383(6598):350-4.

125. Greve JM, Forte CP, Marlor CW, Meyer AM, Hoover-Litty H, Wunderlich D, et al. Mechanisms of receptor-mediated rhinovirus neutralization defined by two soluble forms of ICAM-1. JVirol. 1991;65(11):6015-23.

126. Martin S, Casasnovas JM, Staunton DE, Springer TA. Efficient neutralization and disruption of rhinovirus by chimeric ICAM-1/immunoglobulin molecules. J Virol. 1993;67(6):3561-8.

127. Casasnovas JM, Springer TA. Pathway of rhinovirus disruption by soluble intercellular adhesion molecule 1 (ICAM1): an intermediate in which ICAM-1 is bound and RNA is released. JVirol. 1994;68(9):5882-9.

128. Casasnovas JM, Springer TA. Kinetics and thermodynamics of virus binding to receptor. Studies with rhinovirus, intercellular adhesion molecule-1 (ICAM-1), and surface plasmon resonance. JBiol Chem. 1995;270(22):13216-24.

129. Reisdorph N, Thomas JJ, Katpally U, Chase E, Harris K, Siuzdak G, et al. Human rhinovirus capsid dynamics is controlled by canyon flexibility. Virology. 2003;314(1):34-44.

130. Lewis JK, Bothner B, Smith TJ, Siuzdak G. Antiviral agent blocks breathing of the common cold virus. Proc Natl Acad SciUSA. 1998;95(12):6774-8.

131. Arruda E, Crump CE, Marlin SD, Merluzzi VJ, Hayden FG. In vitro studies of the antirhinovirus activity of soluble intercellular adhesion molecule-1. Antimicrob Agents Chemother. 1992;36(6):1186-91.

132. Nurani G, Lindqvist B, Casasnovas JM. Receptor priming of major group human rhinoviruses for uncoating and entry at mild low-pH environments. JVirol. 2003;77(22):11985-91.

133. Bayer N, Prchla E, Schwab M, Blaas D, Fuchs R. Human rhinovirus HRV14 uncoats from early endosomes in the presence of bafilomycin. FEBS Lett. 1999;463(1-2):175-8.

134. Reischl A, Reithmayer M, Winsauer G, Moser R, Gosler I, Blaas D. Viral evolution toward change in receptor usage: adaptation of a major group human rhinovirus to grow in ICAM-1-negative cells. JVirol. 2001;75(19):9312-9.

135. Ohlin A, Hoover-Litty H, Sanderson G, Paessens A, Johnston SL, Holgate ST, et al. Spectrum of activity of soluble intercellular adhesion molecule-1 against rhinovirus reference strains and field isolates. Antimicrob Agents Chemother. 1994;38(6):1413-5.

136. Crump CE, Arruda E, Hayden FG. Comparative antirhinoviral activities of soluble intercellular adhesion molecule-1 (sICAM-1) and chimeric ICAM-1/ immunoglobulin A molecule. Antimicrob Agents Chemother. 1994;38(6):1425-7.

137. Brioen P, Rombaut B, Boeye A. Hit-and-run neutralization of poliovirus. J Gen Virol. 1985;66(11):2495-9.

138. Plevka P, Lim PY, Perera R, Cardosa J, Suksatu A, Kuhn RJ, et al. Neutralizing antibodies can initiate genome release from human enterovirus 71. Proc Natl Acad Sci U S A. 2014;111(6):2134-9.

139. Huber M, Brabec M, Bayer N, Blaas D, Fuchs R. Elevated endosomal $\mathrm{pH}$ in HeLa cells overexpressing mutant dynamin can affect infection by $\mathrm{pH}$-sensitive viruses. Traffic. 2001;2(10):727-36.
140. Snyers L, Zwickl H, Blaas D. Human rhinovirus type 2 is internalized by clathrin-mediated endocytosis. J Virol. 2003;77(9):5360-9.

141. Gruenberger M, Pevear D, Diana GD, Kuechler E, Blaas D. Stabilization of human rhinovirus serotype 2 against $\mathrm{pH}$ induced conformational change by antiviral compounds. J Gen Virol. 1991;72(2):431-3.

142. Prchla E, Kuechler E, Blaas D, Fuchs R. Uncoating of human rhinovirus serotype 2 from late endosomes. JVirol. 1994;68(6):3713-23.

143. Bayer N, Schober D, Prchla E, Murphy RF, Blaas D, Fuchs R. Effect of bafilomycin A1 and nocodazole on endocytic transport in HeLa cells: implications for viral uncoating and infection. JVirol. 1998;72(12):9645-55.

144. Neubauer C, Frasel L, Kuechler E, Blaas D. Mechanism of entry of human rhinovirus 2 into HeLa cells. Virology. 1987;158(1):255-8.

145. Jurgeit A, McDowell R, Moese S, Meldrum E, Schwendener $\mathrm{R}$, Greber UF. Niclosamide is a proton carrier and targets acidic endosomes with broad antiviral effects. Plos Pathog. 2012;8(10):e1002976.

146. Hewat EA, Blaas D. Nonneutralizing human rhinovirus serotype 2 -specific monoclonal antibody $2 \mathrm{G} 2$ attaches to the region that undergoes the most dramatic changes upon release of the viral RNA. JVirol. 2006;80(24):12398-401.

147. Neumann E, Moser R, Snyers L, Blaas D, HewatEA. A cellular receptor of human rhinovirus type 2 , the very-low-density lipoprotein receptor, binds to two neighboring proteins of the viral capsid. JVirol. 2003;77(15):8504-11.

148. Panjwani A, Strauss M, Gold S, Wenham H, Jackson T, Chou JJ, et al. Capsid protein VP4 of human rhinovirus induces membrane permeability by the formation of a size-selective multimeric pore. Plos Pathog. 2014;10(8):e1004294.

149. Davis MP, Bottley G, Beales LP, Killington RA, Rowlands DJ, Tuthill TJ. Recombinant VP4 of human rhinovirus induces permeability in model membranes. J Virol. 2008;82(8):4169-74.

150. Tosteson MT, Wang H, Naumov A, Chow M. Poliovirus binding to its receptor in lipid bilayers results in particlespecific, temperature-sensitive channels. J Gen Virol. 2004;85(6):1581-9.

151. Danthi P, Tosteson M, Li QH, Chow M. Genome delivery and ion channel properties are altered in VP4 mutants of poliovirus. JVirol. 2003;77(9):5266-74.

152. Tosteson MT, Chow M. Characterization of the ion channels formed by poliovirus in planar lipid membranes. J Virol. 1997;71(1):507-11.

153. Brabec M, Schober D, Wagner E, Bayer N, Murphy RF, Blaas $\mathrm{D}$, et al. Opening of size-selective pores in endosomes during human rhinovirus serotype 2 in vivo uncoating monitored by single-organelle flow analysis. J Virol. 2005;79(2):1008-16.

154. Shivanna V, Kim Y, Chang KO. Endosomal acidification and cathepsin $\mathrm{L}$ activity is required for calicivirus replication. Virology. 2014;464-465:287-95.

155. Harutyunyan S, Kumar M, Sedivy A, Subirats X, Kowalski H, Kohler G, et al. Viral uncoating is directional: exit of the genomic RNA in a common cold virus starts with the poly(A) tail at the 3'-end. Plos Pathog. 2013;9(4):e1003270.

156. Harutyunyan S, Kowalski H, Blaas D. The Rhinovirus subviral a-particle exposes 3'-terminal sequences of its genomic RNA. JVirol. 2014;88(11):6307-17.

157. Carpen O, Pallai P, Staunton DE, Springer TA. Association of intercellular adhesion molecule-1 (ICAM-1) with actincontaining cytoskeleton and alpha-actinin. J Cell Biol. 1992;118(5):1223-34. 
158. Staunton DE, Gaur A, Chan PY, Springer TA. Internalization of a major group human rhinovirus does not require cytoplasmic or transmembrane domains of ICAM-1. J Immunol. 1992;148(10):3271-4.

159. Grunert HP, Wolf KU, Langner KD, Sawitzky D, Habermehl $\mathrm{KO}$, Zeichhardt $\mathrm{H}$. Internalization of human rhinovirus 14 into HeLa and ICAM-1-transfected BHK cells. Med Microbiol Immunol. 1997;186(1):1-9.

160. Prchla E, Plank C, Wagner E, Blaas D, Virus- FR. mediated release of endosomal content in vitro: different behavior of adenovirus and rhinovirus serotype 2. J Cell Biol. 1995;131(1):111-23.

161. Zauner W, Blaas D, Kuechler E, Wagner E. Rhinovirusmediated endosomal release of transfection complexes. JVirol. 1995;69(2):1085-92.

162. Vlasak M, Goesler I, Blaas D. Human rhinovirus type 89 variants use heparan sulfate proteoglycan for cell attachment. JVirol. 2005;79(10):5963-70. 